\title{
Radovan Bacik,
}

Ph.D., Associate Professor, The University of Presov in Presov, Slovakia

ORCID ID, 0000-0002-5780-3838

email: radovan.bacik@unipo.sk

\section{Beata Gavurova,}

Ph.D., Professor, Technical University of Kosice, Slovakia

ORCID ID, 0000-0002-0606-879X

email: beata.gavurova@tuke.sk

Jaroslava Gburova,

Ph.D., The University of Presov in Presov, Slovakia

ORCID ID, 0000-0002-7953-7059

email: jaroslava.gburova@unipo.sk

Correspondence author: beata.gavurova@tuke.sk

\section{POLITICAL MARKETING: IMPACT OF PUBLIC RELATIONS ON THE CHANGE IN VOTER BEHAVIOUR OF CONSUMERS (VOTERS)}

Abstract. Companies use marketing public relations to support the marketing department or product promotion and image-making. The discipline of public relations usually used to be of secondary importance in marketing communication activities for ages. Marketing public relations could affect public awareness at a fraction of the cost of advertising and is often much more credible. Public relations are intended to positively influence development in society by aligning one's own interests with those of the public. Public relations objectives in politics focus on building image, securing market share, or increasing consumer (voter) conviction. Political parties should inform the public of their activities based on truthfulness and without any distortion. The paper aims to theoretically summarize public relations and differences between public relations and advertising and an analysis of the impact of public relations and public relations tools on the change of voting behavior and decision-making of Slovak consumers (voters). The empirical study was carried out based on a research of 362 in Slovakia consumers (voters). The primary information was the actual collection. The sample consisted of 362 respondents. The obtained primary data were processed in the statistical program. The method Pearson's Chi-squared test was used to confirm or reject the stated hypothesis. The subject of the research were consumers living in the region of eastern Slovakia. The obtained results showed statistically significant differences in the perception of tools and public relations methods depending on respondents' education. The findings could be beneficial for several target groups, namely marketing managers in the political field, political parties, political candidates, not only in Eastern Slovakia but within the framework of whole Slovakia. At the same time, they could serve as a source of information and as a basis for deciding and establishing the right tools of public relations in promoting political parties and political candidates.

Keywords: public relations, consumer, image, political marketing, advertising.

Introduction. Political marketing is also related to public relations. It is also true for politicians involved in public offices and processes of governing. In this respect, it is necessary to have the knowledge and skills in personal presentation, rhetoric, mass media communication, and PR. To influence people and win their trust, it is necessary to master communication skills on both interpersonal and mass media levels. Both forms of communication contribute to a better understanding and use of political marketing (Ftorek, 2010). Image building and obtaining market share are crucial public relations objectives (Yagmur and Aksu, 2020). Another goal is to persuade the target audience of the benefits of buying products, services, etc. These objectives are to predetermine the processing of the message sent to a specific target group.

Cite as: Bacik, R., Gavurova, B., \& Gburova, J. (2021). Political Marketing: Impact of Public Relations on the Change in Voter Behaviour of Consumers (Voters). Marketing and Management of Innovations, 2, 40-48. http://doi.org/10.21272/mmi.2021.2-03

40 

Consumers (Voters)

It stands to mention that target groups could be: employees, political figures, youth, undergraduates, and other groups. The main objective of PR must be tailored to individual tasks that will enable us to get to the final result. Often companies or organizations hold various events to which they invite celebrities or organize press conferences. Each event offers a different story for different audiences (Ingram, 2019). Public relations aim to create mutual understanding and goodwill between organizations and the target audience. While most companies would undoubtedly agree that maintaining a good reputation, especially among consumers, is important, other companies look at it differently. They do not build goodwill but use it as a means to achieve their primary goals (Black, 2013; Zauskova and Rezníckova, 2020).

On the one hand, public relations could be understood as continuous public relations. They are freely accessible. On the other hand, public relations could be understood as the general public opinion. It is public opinion that implies the importance of the majority opinion and stands for different opinions on products, things, or people (L'etang, 2009; Mudrík and Fedorko, 2010). Public relations discipline usually used to be of secondary importance in marketing communication activities for ages (Uslu et al., 2020). With the political, economic, and technological developments of the 1990s, marketers recognized that it was difficult to reach their marketing aims only by using mass advertising. To establish and maintain longterm relationships with customers, marketers began to use the characteristic facilitator features PR more and more. The marketing PR field arose with the growing need for PR in product brand communications (Flisikowski and Kucharska, 2018). During this time, the PR had a significant impact on developing the Integrated Marketing Communication (IMC) approach, which means managing all communication tools in a long-term harmony by meeting consumers at all contact points in a single message and shared aims (Tuncel, 2009). Several authors Pieczka (2019), Spicer (1991), Botan and Taylor (2004), Hodis (2017), and McKie and Munshi (2005), pointed that public relations involve a variety of programs designed to promote or protect a company's image or its products. Today, many companies use marketing public relations to support the marketing department or product promotion and image-making. Marketing public relations could affect public awareness at a fraction of the cost of advertising and is often much more credible. The main public relations tools are publications, events, news, speeches, public service activities, and identity media.

Literature Review. The emergence of public relations (PR) dates back to the early beginnings of civilization. People are starting to communicate with each other, defend their opinions, and promote them, and this is when some elements of public relations begin to form (Bacík and Gburova, 2012; Paetsch et al., 2017). Although public relations and marketing trade presses regularly discuss the conflict between the functions, academic researchers focused on the issue primarily in the 1980s and 1990s. The drop in public relations and marketing encroachment research does not parallel a drop in encroachment in practice, especially in light of today's social media environment (Gesualdi, 2019; Cepel, 2020; Civelek et al., 2020). Current social media development became an important tool for not only communications with customers. Thus, their role in communications with internal stakeholders remains essential (Bilan et al., 2020). Kowalski (2007) lists various forms of public relations such as propaganda, public information, publicity. Humanity needs communication, cooperation, and reconciliation to function. All these are the main elements of public relations. The author describes that Greek philosophers have already written about public opinion, although they did not use the term public opinion. The Roman Empire devoted more time and space to public relations. Public relations could be defined as a means to support products, services, people, activities, places, ideas, organizations, or nations. PR has a greater impact on people, on public opinion than advertising (Stefko et al., 2013). Hejlova (2015) states that PR and propaganda are constituents of communication as they share a common goal - to convince. Whether we talk about propagandists, press agents, officials who provide information to the public, PR workers, political campaign specialists or lobbyists, they all have a common goal - to influence public buying behavior. 

Consumers (Voters)

Jo (2018) and Karlícek and Kral (2011) described the difference between PR and propaganda. These terms are used interchangeably, and sometimes PR is mistaken for the word «propaganda». Propaganda generally means dissemination, a one-way flow of information with a strong desire to influence and persuade individuals or society. PR is a discipline that informs and influences key groups of an organization. However, one fundamental factor that differs PR from propaganda - PR seeks to achieve its objectives credibly, considering the other party's interests. According to many authors, public relations would play a key role in the future of marketing communications (Stefko et al., 2015; Ferencakova et al., 2020). Advertising and PR are components of marketing communication and have their own specifics. Sometimes they are closely linked and even interchangeable (Hornak, 2010; Dorcak et al., 2015; Goker and Ayar, 2020). Corporate public relations often aim at persuading the public, investors, partners, employees, and other stakeholders to maintain a certain opinion of products, services, policy decisions, company management, etc. (Cameron et al., 2008; Gavurova et al., 2018). In this regard, corporate communications are needed to be developed in all these directions using the social dialogue tools (Bilan et al., 2019) in the framework of measures aimed at maintaining the corporate social responsibility of the firm (Çera et al., 2020; Vo et al., 2020). Bowen et al. (2010) state that the function of public relations is prevalent and growing; fragmentation of the media and the growth of multiple sources of news means that public relations are on the rise, while traditional forms of mass communication are on the decline. Butterick (2011) defines the main difference between advertising and PR. Typically, the ad addresses customers or potential customers, while public relations target a much wider range of target groups. Some audience members do not have a direct business relationship with the organization. That is when PR comes to the scene as it reaches out to a wide range of communication needs and goals that are not necessarily focused on potential sales. The primary goal of an ad is to sell a product, service, or idea. Achieving sales is the primary goal. The advertiser pays for space and time in a medium and strictly and unconditionally controls the content of an ad. The role of PR is significantly different from advertising and is often misrepresented as media relations. PR's primary task is not to sell, but above all to inform, create understanding, understanding, trust, loyalty, educate and provoke debate or exchange of views (Kopecky, 2013; Fedorko and Kakalejcík, 2015). Kotler and Armstrong (2011) stated that public relations could significantly impact public awareness at a much lower cost than advertising. In PR, the company does not pay for space and time in the media. Instead, it pays its staff to develop and disseminate information and manage events. If a company develops an interesting story or event, it could be acquired by several different media and have the same effect as advertising that costs millions of dollars. Such a stunt has more credibility than advertising.

Methodology and research methods. The research aimed to analyze the impact of public relations and public relations tools on the change of voting behavior and decision-making of Slovak consumers (voters). The subject of the research was consumers living in the region of eastern Slovakia. The primary information was obtained by collecting data using a questionnaire - the method which is often used to collect vast amounts of data quickly. The survey sample was selected by random sampling. The obtained primary data were subsequently processed in the statistical program Statistica. The Pearson's Chisquared test method was used to confirm or reject the established hypothesis.

To determine the goal of the research, we set the following hypothesis:

$\mathrm{H} 1$ : It is assumed that there are statistically significant differences in the perception of tools and methods of public relations depending on respondents' education.

Results. The sample consisted of 362 respondents. Of the sample of 362 respondents, 200 were women and 162 men. The largest group represented is the group of respondents with secondary education with school-leaving exams (maturity), i.e., 173 respondents. The second largest group consisted of respondents with higher education (second degree) - 121 respondents. Respondents with higher education (first degree) accounted represent 46 respondents. 19 respondents with secondary education 
R., Bacik, B., Gavurova, J., Gburova. Political Marketing: Impact of Public Relations on the Change in Voter Behaviour of Consumers (Voters)

without a school-leaving exam (maturity) represent. The smallest group consisted of 3 respondents with higher education (third-degree). The questionnaire aimed to ascertain whether public relations have a greater impact on voters when choosing a particular political party than advertising.

Table 1. The influence of public relations and advertising when choosing a political party

\begin{tabular}{ccccc}
\hline & Number & Cumulative number & Relative number & Cumulative relative number \\
\hline Strongly disagree & 3 & 3 & $0.83 \%$ & $0.83 \%$ \\
Disagree & 17 & 20 & $4.70 \%$ & $5.52 \%$ \\
I do not know & 99 & 119 & $27.35 \%$ & $32.87 \%$ \\
Agree & 116 & 235 & $32.04 \%$ & $64.92 \%$ \\
Strongly agree & 127 & 362 & $35.08 \%$ & $100.00 \%$ \\
In total & 362 & 362 & $100.00 \%$ & $100.00 \%$ \\
\hline
\end{tabular}

Sources: developed by the authors.

Table 1 shows the results of the research. Notably, $35.08 \%$ of respondents strongly agree that public relations have a greater influence on a political party's choice than advertising. A further $32.04 \%$ of respondents tend to agree with this claim. In turn, 99 respondents (27.35\%) expressed a neutral attitude, which means that both public relations and advertising are strong influencers. Only 17 respondents think that public relations do not have a greater influence on the choice of a political party than advertising, and only 3 respondents disagree with the statement. The following question aimed to ascertain whether respondents think public relations are a key tool when choosing a political party.

Table 2. Public relations as a key tool in selecting a political party

\begin{tabular}{ccccc}
\hline & Number & Cumulative number & Relative number & Cumulative relative number \\
\hline Strongly disagree & 9 & 9 & $2.49 \%$ & $2.49 \%$ \\
Disagree & 16 & 25 & $4.42 \%$ & $6.91 \%$ \\
I do not know & 125 & 150 & $34.53 \%$ & $41.44 \%$ \\
Agree & 147 & 297 & $40.61 \%$ & $82.04 \%$ \\
Strongly agree & 65 & 362 & $17.96 \%$ & $100.00 \%$ \\
In total & 362 & 362 & $100.00 \%$ & $100.00 \%$ \\
\hline
\end{tabular}

Sources: developed by the authors.

Table 2 demonstrates that 147 respondents agree that public relations are a key tool when selecting a political party. A slightly smaller share, $34.53 \%$ of respondents expressed a neutral attitude, which means that they are not entirely sure whether public relations are a key tool in that matter. 65 respondents strongly agreed that public relations are key when choosing a political party. 16 respondents chose the option «Disagree», and 9 respondents - «Strongly disagree». The next question aimed to determine which public relations tools or methods have the most influence when choosing a political party (Table 3 ).

Table 3. Tools and methods of public relations when choosing a political party

\begin{tabular}{ccccc}
\hline & Number & $\begin{array}{c}\text { Cumulative } \\
\text { number }\end{array}$ & $\begin{array}{c}\text { Relative } \\
\text { number }\end{array}$ & $\begin{array}{c}\text { Cumulative } \\
\text { relative number }\end{array}$ \\
\hline Advertising campaigns & 132 & 132 & $36.46 \%$ & $36.46 \%$ \\
Press conferences & 51 & 183 & $14.09 \%$ & $50.55 \%$ \\
Presentations of organizations, political parties & 54 & 237 & $14.92 \%$ & $65.47 \%$ \\
Sponsorships & 7 & 244 & $1.93 \%$ & $67.40 \%$ \\
Informal meetings with journalists & 17 & 261 & $4.70 \%$ & $72.10 \%$ \\
Meetings & 101 & 362 & $27.90 \%$ & $100.00 \%$ \\
In total & 362 & 362 & $100.00 \%$ & $100.00 \%$ \\
\hline
\end{tabular}

Sources: developed by the authors. 

Consumers (Voters)

Based on the results presented in Table 3, it could be stated that the largest portion of the respondents $(36.46 \%)$ claim that advertising campaigns are the most important method that influences the respondents when choosing a political party. $27.90 \%$ of respondents said that the most influential tool is meetings. 54 respondents chose the option presentation of organizations, political parties. 51 respondents chose the option press conference. Another group of respondents stated that informal meetings with journalists are important to them and could influence them when choosing a political party the most. Only 7 respondents selected the option of sponsorship. Table 4 presents the answers question, which aims to determine whether the respondents think personal communication of political parties with voters is important.

Table 4. The importance of personal communication between a political party and voters

\begin{tabular}{ccccc}
\hline & Number & Cumulative number & Relative number & Cumulative relative number \\
\hline Strongly disagree & 3 & 3 & $0.83 \%$ & $0.83 \%$ \\
Disagree & 7 & 10 & $1.93 \%$ & $2.76 \%$ \\
I do not know & 36 & 46 & $9.94 \%$ & $12.71 \%$ \\
Agree & 82 & 128 & $22.65 \%$ & $35.36 \%$ \\
Strongly agree & 234 & 362 & $64.64 \%$ & $100.00 \%$ \\
In total & 362 & 362 & $100.00 \%$ & $100.00 \%$ \\
\hline
\end{tabular}

Sources: developed by the authors.

234 respondents, i.e., $64.64 \%$, believe that personal communication between political parties and voters is very important. 82 respondents are in favor of personal communication. $9.94 \%$ of respondents chose a neutral approach, which means they do not know if personal communication between a political party and voters is important. Only 7 respondents said they disagree with the view that personal communication between a political party and voters is important, and 3 respondents strongly disagreed with the suggestion. Table 4 consists of the answers question aimed to find whether respondents think that political meetings of political parties with voters are more effective and credible than interviews and discussions on television.

Table 5. Efficiency and credibility of personal meetings versus TV interviews and discussions

\begin{tabular}{ccccc}
\hline & Number & Cumulative number & Relative number & Cumulative relative number \\
\hline Strongly disagree & 7 & 7 & $1.93 \%$ & $1.93 \%$ \\
Disagree & 17 & 24 & $4.70 \%$ & $6.63 \%$ \\
I do not know & 75 & 99 & $20.72 \%$ & $27.35 \%$ \\
Agree & 145 & 244 & $40.06 \%$ & $67.40 \%$ \\
Strongly agree & 118 & 362 & $32.60 \%$ & $100.00 \%$ \\
In total & 362 & 362 & $100.00 \%$ & $100.00 \%$ \\
\hline
\end{tabular}

Sources: developed by the authors.

The largest group of respondents $(40.06 \%)$ agree with this statement and think that personal meetings of political parties with voters are more effective and credible than interviews and discussions on television. A slightly smaller group of respondents $(32.60 \%)$ strongly agree that face-to-face meetings are more effective and boost voters' confidence in a political party. Besides, 75 respondents $(20.72 \%)$ cannot assess whether personal meetings are more effective than discussions on television. 17 respondents do not consider personal meetings of political parties with voters more effective than discussions on television. 7 respondents strongly oppose and disagree with this statement. The ultimate goal of most statistical tests is to evaluate the relationship between variables. When testing statistical hypotheses, it is first necessary to establish the null hypothesis $(\mathrm{H} 0)$, which expresses the independence of variables. It is followed by the formulation of an alternative hypothesis $(\mathrm{H} 1)$ to prove the truthfulness of the statement, which most often 
expresses the relationship between variables. The significance level $(a)$ is at $5 \%$ for all hypotheses $(p=$ 0.05 ). If $p<0.05$, the alternative hypothesis is accepted and the null hypothesis is rejected, i. e. there is a relationship between variables. If $p>0.05$, the alternative hypothesis is rejected, and the null hypothesis is accepted, i. e. there is no relationship between variables (Rimarcík, 2007).

The research problem aims to find out whether there are statistically significant differences in the perception of tools and methods of public relations depending on respondents' education. For the given research problem, the following alternative hypothesis was set:

$\mathrm{H} 1$ : It is assumed that there are statistically significant differences in the perception of tools and methods of public relations depending on respondents' education.

Table 6. Education of respondents vs. tools and methods of public relations

\begin{tabular}{|c|c|c|c|c|c|c|c|}
\hline & Meetings & $\begin{array}{l}\text { Informal } \\
\text { meetings with } \\
\text { journalists }\end{array}$ & $\begin{array}{c}\text { Presentations of } \\
\text { organizations, } \\
\text { political parties }\end{array}$ & $\begin{array}{l}\text { Advertising } \\
\text { campaigns }\end{array}$ & Sponsorships & $\begin{array}{c}\text { Press } \\
\text { conferences }\end{array}$ & In total \\
\hline Secondary & & & & & & & \\
\hline $\begin{array}{l}\text { without school- } \\
\text { leaving exam }\end{array}$ & 12 & 0 & 0 & 5 & 0 & 2 & 19 \\
\hline $\begin{array}{c}\text { Secondary with } \\
\text { school-leaving } \\
\text { exam }\end{array}$ & 48 & 3 & 32 & 68 & 3 & 19 & 173 \\
\hline $\begin{array}{c}\text { Higher } \\
\text { (1st degree) }\end{array}$ & 8 & 7 & 5 & 12 & 2 & 12 & 46 \\
\hline $\begin{array}{c}\text { Higher } \\
\left(2^{\text {nd }} \text { degree }\right)\end{array}$ & 33 & 7 & 17 & 43 & 2 & 19 & 121 \\
\hline $\begin{array}{c}\text { Higher } \\
\text { (3rd degree) }\end{array}$ & 0 & 0 & 0 & 3 & 0 & 0 & 3 \\
\hline In total & 101 & 17 & 54 & 131 & 7 & 52 & 362 \\
\hline
\end{tabular}

Sources: developed by the authors.

$\mathrm{HO}$ : There is no significant difference between the variables analyzed.

$\mathrm{H} 1$ : There is a significant difference between the variables analyzed.

Table 7. Chi-squared test of differences in tools and methods of public relations

\begin{tabular}{cccc}
\hline & Value & $\mathrm{df}$ & Sig \\
\hline Pearson $X^{2}$ & 46.0048 & 20 & 0.001 \\
$\mathrm{~N}$ & & & 362 \\
\hline
\end{tabular}

Sources: developed by the authors.

The Pearson's Chi-squared test was used to determine the differences between variables. The significance level was set at $a=0.05$. Based on the values given in Table 7 , it could be concluded that there is no statistically significant dependence in the perception of instruments and methods of public relations and respondents' education. Since $p=0.001$, which is lower than the level $a=0.05$, the statistical hypothesis $\mathrm{HO}$ was rejected. In turn, its alternative was recommended. From the above, it is clear that there is a significant difference between the variables analyzed, which means that the basic hypothesis $\mathrm{H} 1$ is accepted.

Conclusions. According to respondents, the most used marketing communication tool when choosing a political party is public relations, followed by advertising, personal selling, and sales promotion. Therefore, it is recommended political parties incorporate various means of advertising and public relations into their political campaigns to reach out to a wider group of voters. 

Consumers (Voters)

According to the research, $35 \%$ of respondents stated public relations have a greater influence on voters when deciding for a particular political party. $32 \%$ of respondents think that PR influences them more than advertising. The data suggest that political parties should make greater PR use and include this tool in their campaigns. Generally, TV advertising appeals to many citizens/voters, but sometimes these ads are annoying, inefficient, and even bothersome. PR is a relatively new and atypical instrument, which is also why political parties should make greater use of it. From public relations tools, respondents chose advertising campaigns to be the tool that convinces them to choose a political party and change their preferences the most. Another tool the respondents chose was meetings. Other tools were presentations of organizations/ political parties and press conferences. It implies that potential voters want to hear points of agenda of a political party, not just read them out of leaflets or billboards. That is closely related to the next item in the questionnaire. It aimed to determine whether personal meetings of politicians with voters are more convincing than interviews and discussions on television. Respondents agreed. The respondents also agreed with this statement that personal meetings are more credible. $39 \%$ of respondents said they agree, and another $32 \%$ said they strongly agree. The findings showed that personal meetings of political parties with voters are a must for any political party as they could change voters' minds. Besides, it was confirmed by the answers to the questionnaire's item on whether personal communication of a political party with voters is important. Up to $64 \%$ of respondents stated that they strongly agree that personal communication is important. Another group of $22.7 \%$ of respondents agreed, which means they agree with this statement. Thus, it follows that political parties should not be afraid to meet their voters in towns and municipalities.

Acknowledgement. VEGA 1/0609/19 «Research on the development of electronic and mobile commerce in the aspect of the impact of modern technologies and mobile communication platforms on consumer behavior and consumer preferences».

Author Contributions: prepared the outline of the paper, R. B., B. G. and J. G.; wrote abstract, R. B. and B. G.; developed theoretical background and literature review, J. G. and R. B.; provided data and prepared methodology, B. G.; performed the analysis and visualization of results, R. B. and B. G.; wrote discussion, J. G.; was responsible for references control, R. B.

\section{References}

Bacík, R., \& Gburova, J. (2012). Public relations v súcasnom manažmente. Presov: Bookman, s.r.o.

Bartok, O. (2018). The Use of CSR in E-Commerce as a Way to Compete. Journal of Competitiveness, 10(4), 5-20. [Google Scholar] [CrossRef]

Bilan, S., Mishchuk, H., Samoliuk, N., \& Ostasz, G. (2019). Effectiveness of social dialogue in the system of sustainable economic development factors. In Proceedings of the 34th International Business Information Management Association Conference, IBIMA (pp. 13303-13313).

Bilan, Y., Mishchuk, H., Samoliuk, N., \& Mishchuk, V. (2020). Gender discrimination and its links with compensations and benefits practices in enterprises. Entrepreneurial Business and Economics Review, 8(3), 189-203. [Google Scholar] [CrossRef]

Black, S. (2013). Practice of public relations. Routledge. [Google Scholar]

Botan, C. H., \& Taylor, M. (2004). Public relations: State of the field. Journal of communication, 54(4), 645-661. [Google Scholar] [CrossRef]

Bowen, S. A., Rawlins, B., \& Martin, T. R. (2010). An Overview of The Public Relations Function. New York: Business Expert Press. [Google Scholar]

Butterick, K. J. (2011). Introducing Public Relations Theory and Practice. [Google Scholar]

Cameron, G. T., Wilcox, D. L., Reber, B. H., \& Shin, J. H. (2008). Public relations today: Managing competition and conflict. Boston, MA: Pearson Education, Inc. Callison, C.(2004). The good, the bad, and the ugly: Perceptions of public relations practitioners. Journal of Public Relations Research, 16(4), 371-389. [Google Scholar]

Cepel, M. (2019). Social and Cultural Factors and their Impact on the Quality of Business Environment in the SME Segment. International Journal of Entrepreneurial Knowledge, 7(1), 65-73. [Google Scholar] [CrossRef]

Çera, G., Belas, J., Marousek, J., \& Çera, E. (2020). Do Size and Age Of Small and Medium-Sized Enterprises Matter in Corporate Social Responsibility?. Economics \& Sociology, 13(2), 86-99. [Google Scholar] [CrossRef] 
Civelek, M., Gajdka, K., Světlik, J., \& Vavrecka, V. (2020). Differences in the usage of online marketing and social media tools: evidence from Czech, Slovakian and Hungarian SMEs. Equilibrium. Quarterly Journal of Economics and Economic Policy, 15(3), 537-563. [Google Scholar]

Dorcak, P., Strach, P., \& Pollak, F. (2015). Analytical view of the perception of selected innovative approaches in marketing communications. Quality Innovation Prosperity, 19(1), 74-84. [Google Scholar] [CrossRef]

Fedorko, R., \& Kakalejcik, L. (2015). Search Engine Optimization and its Importance in the Purchase Process. In Proceedings of the Central european conference in finance and economics (CEFE 2015) (pp. 155-163).

Ferencakova, L., Gajdka, K., Netek, V., \& Kapoun, P. (2020). Engaging customers on facebook coffee shops'brand-fan pages. International Journal of Entrepreneurial Knowledge, 8(1), 65-75. [Google Scholar] [CrossRef]

Flisikowski, K., \& Kucharska, W. (2018). The condition of economies. Do most valuable global brands matter?. Equilibrium Quarterly Journal of Economics and Economic Policy, 13(2), 251-264. [Google Scholar] [CrossRef]

Ftorek, J. B. (2010). Public relations a politika: Kdo a jak rídí nase osudy s nasím souhlasem. Praha: Grada Publishing. [Google Scholar]

Gavurova, B., Bacik, R., Fedorko, R., \& Nastisin, L. (2018). The customer's brand experience in the light of selected performance indicators in the social media environment. Journal of Competitiveness, 10(2), 72. [Google Scholar]

Gesualdi, M. (2019). Revisiting the relationship between public relations and marketing: Encroachment and social media. Public Relations Review, 45(2), 372-382. [Google Scholar] [CrossRef]

Göker, G., \& Ayar, İ. (2020). Intermediary Role Of Nostalgia Tendency In The Effect Of Electronic Word Of Mouth Communication On Tourists' Destination Visit Intentions. Journal of Tourism and Services, 11(20), 44-59. [Google Scholar] CrossRef

Hejlova, D. (2015). Public relations. Praha: Grada Publishing.

Hodis, G. M. (2017). Key roles played by PR/Communication departments: The perspective of senior communication practitioners from Aotearoa New Zealand. Asia Pacific Public Relations Journal, 18. [Google Scholar]

Hornak, P. (2010). Reklama: teoreticko-historické aspekty reklamy a marketingovej komunikacie. Zlín: VeRBuM.

Ingram, D. (2019). Transparency, Public Relations and the Mass Media: Combating the Hidden Influences in News Coverge Worldwide. Journalism \& Mass Communication Quarterly, 96(2), 637-639 [CrossRef]

Jo, S. (2018). In search of a causal model of the organization-public relationship in public relations. Social Behavior and Personality: an international journal, 46(11), 1761-1770. [Google Scholar] [CrossRef]

Karlicek, M. \& Kral, P. (2011). Marketingova komunikace. Praha: Grada Publishing.

Kopecky, L. (2013). Public relations: dějiny-teorie-praxe. Grada Publishing as. [Google Scholar]

Kotler, P. \& Armstrong, G. (2011). Principles of Marketing. New Jersey: Pearson Education. [Google Scholar]

Kowalski, J. T. (2007). Public relations in schools. Hall: Pearson Merrill Prentice.

L'etang, J. (2009). Public Relations. Zakladní teorie, praxe, kritické prístupy. Praha: Portal.

McKie, D., \& Munshi, D. (2005). Tracking trends: Peripheral visions and public relations. Public Relations Review, 31(4), 453-

457. [Google Scholar] [CrossRef]

Mudrík, M., \& Fedorko, R. (2010). Business Via Google-New Possibilities and the Future. Management, 448-455.

Paetsch, M., Dorcak, P., Pollak, F., Strba, L., \& Krsak, B. (2017). Developing a framework for future mobile data pricing. Quality innovation prosperity, 21(2), 84-108. [Google Scholar] [CrossRef]

Pieczka, M. (2019). Looking back and going forward: The concept of the public in public relations theory. Public Relations Inquiry, 8(3), 225-244. [Google Scholar] [CrossRef]

Spicer, C. H. (1991). Communication functions performed by public relations and marketing practitioners. Public Relations Review, 17(3), 293-305. [Google Scholar] [CrossRef]

Stefko, R., Dorcak, P., Bacik, R., Ferencova, M., Gburova, J., Kerul', R., Pollak, F., Suhanyi, L., Fedorko, I., Fedorko, R., Mudrík, M., \& Zajacova, L. (2013). Marketing nasej súcasnosti. Bookman. Retrieved from [Link]

Stefko, R., Kiral'ova, A., \& Mudrik, M. (2015). Strategic marketing communication in pilgrimage tourism. Procedia-Social and Behavioral Sciences, 175, 423-430. [Google Scholar] [CrossRef]

Tuncel, H. (2009). Integrated Marketing Communication with the understanding of Public Relations. Istanbul Universite silletisim Fakultesi Dergisi, 35, 115-136. [Google Scholar]

Uslu, A., Alagöz, G., \& Güneş, E. (2020). Socio-cultural, Economic, and Environmental Effects of Tourism from the Point of View of the Local Community. Journal of Tourism and Services, 11(21), 1-21. [Google Scholar] [CrossRef]

Vo, D. H., Van, L. T. H., Dinh, L. T. H., \& Ho, C. M. (2020). Financial inclusion, corporate social responsibility and customer loyalty in the banking sector in Vietnam. Journal of International Studies, 13(4), 9-23. [Google Scholar] [CrossRef]

Wroblowska, Z. (2016). Requirements for brand managers and product managers responsible for competitiveness of product and brands. Journal of Competitiveness, 8(3). [Google Scholar] [CrossRef]

Yagmur, Y., \& Aksu, A. (2020). Destination Image of Antalya from the Perspectives of Tourists Staying in Hospitality Establishments with the Concept of Halal Tourism. Journal of Tourism and Services, 11(21), 103-128. [Google Scholar] [CrossRef] Zauskova, A., \& Rezníckova, M. (2020). SoLoMo marketing as a global tool for enhancing awareness of eco-innovations in Slovak business environment. Equilibrium. Quarterly Journal of Economics and Economic Policy, 15(1), 133-150. [Google Scholar] CrossRef 
R., Bacik, B., Gavurova, J., Gburova. Political Marketing: Impact of Public Relations on the Change in Voter Behaviour of Consumers (Voters)

Радован Бачик, Ph.D., доцент, Пряшівський університет в Пряшеві, Словаччина

Беата Гавурова, Ph.D., професор, Технічний університет в Кошице, Словаччина

Ярослава Гбурова, Ph.D., Пряшівський університет в Пряшеві, Словаччина

Політичний маркетинг: вплив ефективності управління зв'язками з громадськістю на зміну поведінки споживачів (виборців)

У сучасному конкурентному середовищі компанії приділяють особливу увагу управлінню зв'язками з громадськістю при просуванні товарів та створенні іміджу, тоді як раніше зв'язки з громадськістю тривалий час були другорядними у маркетинговій комунікаційній діяльності. Авторами зазначено, що ефективне управління зв'язками з громадськістю дозволяє впливати на рівень обізнаності суспільства узгоджуючи власні інтереси з суспільними при мінімальних витратах та високому рівні довіри. У статті наголошено, що в політичній діяльності, зв'язки з громадськістю спрямовані на фрормування іміджу, завоювання частки виборців або їх переконання. Однак, авторами зазначено, що політичні партії повинні дотримуватись принципів правдивості та уникати будь-яких інформаційних спотворень при інформуванні громадськості. Метою статті $є$ визначення впливу ефективності управління зв'язками з громадськістю на поведінку та прийняття рішень словацькими споживачами (виборцями). Для досягнення поставленої мети проведено теоретичний аналіз наукових напрацювань щодо досліджуваного питання та визначено відмінності між зв'язками з громадськістю та рекламою. Емпіричне дослідження проведено на основі панельних даних, сформованих на основі результатів опитування 362 виборців східного регіону Словаччини. Для опрацювання отриманих даних застосовано статистичне програмне забезпечення. Для підтвердження або відхилення сформованих гіпотез застосовано критерій Хі-квадрат Пірсона. За результатами дослідження встановлено статистично значущі відмінності у сприйнятті інструментарію управління зв'язками з громадськістю залежно від освіти респондентів. Висновки дослідження мають практичне значення та можуть бути корисними менеджерам політичного маркетингу, політичним партіям, політичним діячам Словаччини. Разом із тим вони можуть бути використані у якост інформаційного джерела та основою для формування ефективного набору інструментів управління зв'язками 3 громадськістю при просуванні політичних партій та кандидатів.

Ключові слова: зв'язки з громадськістю, споживач, імідж, політичний маркетинг, реклама. 